\title{
Estimación Tier II de emisión de metano entérico en hatos de vacas lactantes en Querétaro, México
}

\section{Tier II estimation of enteric methane emission in dairy cow herds in Querétaro, México}

\author{
Daniela Morante Lópeza, Aurelio Guevara Escobara, Humberto Suzán Azpiria, \\ Vicente Lemus Ramírezb, Carlos Francisco Sosa Ferreyraa
}

\begin{abstract}
RESUMEN
El metano $\left(\mathrm{CH}_{4}\right)$ contribuye al cambio climático y su fuente antropogénica más importante es la fermentación entérica del ganado. A nivel continental el Panel Intergubernamental de Cambio Climático establece factores de emisión entérica de $\mathrm{CH}_{4}$ por defecto (Tier I); pero las decisiones y evaluación de la mitigación necesitan estimaciones más exactas. Así, el objetivo fue calcular la emisión de metano entérico de hatos de vacas Holstein-Friesian en Querétaro, México con datos de pesaje de leche (Tier II). Las curvas de lactación se modelaron con la función gamma incompleta por lactancia y hato. Un total de 11,092 lactancias del 2007 tuvieron un rendimiento ajustado a 305 días (d) de 9,985 $\mathrm{kg}$ leche. La curva de lactancia fue diferente entre primíparas y multíparas; la duración de la lactancia fue $365 \pm 21$ días. Durante la lactancia, la emisión entérica para primíparas y multíparas a 305 días fue $165.7 \pm 3.8$ y $181.6 \pm 8.3 \mathrm{~kg}$

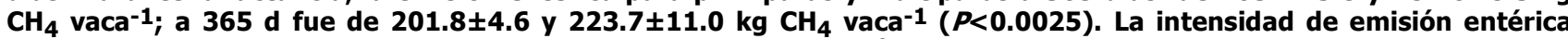
fue semejante entre primíparas y multíparas (18 y $19 \mathrm{~g} \mathrm{CH}_{\mathbf{4}} \mathrm{kg}^{-1}$ leche), similar a lo reportado en la literatura para vacas de alta producción intensiva. Los registros de rendimiento fueron útiles para caracterizar el rendimiento, duración de la lactancia y el efecto de número de lactancia en su influencia sobre los estimados de intensidad de emisión entérica.
\end{abstract}

PALABRAS CLAVE: Cambio climático, Factor de emisión, GEI, Mitigación, Metano.

\begin{abstract}
Methane $\left(\mathrm{CH}_{4}\right)$ contributes to climatic change and livestock enteric fermentation is the most important anthropogenic source. The Intergovernmental Panel on Climate Change establishes continental default emission factors for enteric methane (Tier I); but decisions and evaluation of mitigation needs more precise estimates. Therefore, the objective was to calculate the enteric emission of Holstein-Friesian herds in Queretaro, México using milk test-day records (Tier II). Lactation curves were modeled using the incomplete gamma function according to lactation number and herd. A total of 11,092 lactations from 2007 had an average 305 d milk yield of 9,985 kg. Lactation curve was different between primiparous and multiparous; average days in milk were $365 \pm 21 \mathrm{~d}$. During lactation, the primiparous and

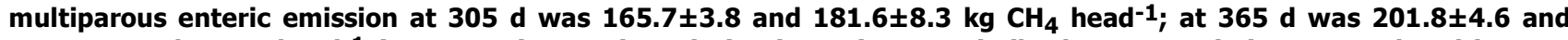
$223.7 \pm 11.0 \mathrm{~kg} \mathrm{CH}_{4}$ head-1 $^{-1}(P<0.0025)$. Enteric emission intensity was similar between primiparous and multiparous (18 and $19 \mathrm{~g} \mathrm{CH}_{4} \mathrm{~kg}^{-1}$ milk), similar to reports in the literature for high yielding cows. Test day records were useful to characterize yield, days in milk and parity influencing the estimates of enteric emission intensity.
\end{abstract}

KEY WORDS: Climatic change, Emission factor, GHG, Mitigation, Methane.

\section{INTRODUCCIÓN}

Disminuir las emisiones de gases con efecto invernadero (GEI) es una estrategia de

\section{INTRODUCTION}

Attempts to reduce greenhouse gases (GHG) are aimed at mitigating the causes of climate

Recibido el 6 de mayo de 2005. Aceptado el 4 de septiembre de 20015.

a Facultad de Ciencias Naturales. Universidad Autónoma de Querétaro. 76230. Juriquilla, Querétaro. México. guevara@uaq.mx. Correspondencia al segundo autor.

b Facultad de Medicina Veterinaria y Zootecnia. Universidad Nacional Autónoma de México. México. 
mitigación de las causas del cambio climático. Los inventarios de GEI miden los avances de los países en la disminución de estas emisiones en los sectores productivos. En 2010 las emisiones de GEI en México fueron $748,252 \mathrm{Gg}$ de bióxido de carbono equivalente (Ceq); siendo un $\mathrm{Gg}$ igual a $10^{9} \mathrm{~g}(1)$. La masa de gas emitida a la atmósfera y el efecto forzante radiativo de cada GEI determinan la importancia del $\mathrm{CO}_{2}$, $\mathrm{CH}_{4}, \mathrm{~N}_{2} \mathrm{O}, \mathrm{O}_{3}$, entre otros. En los inventarios de GEI, el metano $\left(\mathrm{CH}_{4}\right)$ merece atención porque su efecto forzante radiativo es de 25 a 34 veces mayor al $\mathrm{CO}_{2}$, entonces un $1 \mathrm{~g} \mathrm{CH}_{4}$ es igual a $25 \mathrm{~g} \mathrm{Ceq}(2)$.

El papel de la ganadería en el contexto de las emisiones de GEI tiene gran debate e importancia $(3,4,5)$. Para México, la emisión de $\mathrm{CH}_{4}$ por fermentación entérica fue el $20.1 \%$ del $\mathrm{CH}_{4}$ total, después de las emisiones fugitivas en la producción de petróleo(6). $\mathrm{El} \mathrm{CH}_{4}$ entérico y por excretas suman de 75 a $95 \%$ de las emisiones totales de GEI en las granjas lecheras de 38 países(7). En el mundo, México ocupaba el $11^{\circ}$ lugar en emisión de $\mathrm{CH}_{4}$ entérico con $22,244 \mathrm{Gg}$ en 1998(8). Sin embargo, para 2010 se reportan $37,961 \mathrm{Gg}$ Ceq por fermentación entérica y 7,553 Gg Ceq a partir del manejo de excretas; siendo 92,184 Gg Ceq el total para la categoría agricultura(1). Para el sector lechero mexicano la emisión fue de $144,000 \mathrm{Gg} \mathrm{CH}_{4}$ en 1970 y $270,000 \mathrm{Gg} \mathrm{CH}_{4}$ en 2010 (9). Otro estudio estimaba en 1995 una emisión de $285 \mathrm{Gg}$ $\mathrm{CH}_{4}(10)$. Dado el amplio rango de las cifras, es importante reducir la incertidumbre en las estimaciones investigando sobre los factores e intensidades de emisión.

Los países adheridos a la Convención Marco sobre el Cambio Climático acordaron reportar anualmente sus inventarios de emisión de GEI según las guías del Panel Intergubernamental del Cambio Climático (IPCC) usando alguno de tres Tier o niveles de precisión(11). Para la emisión de $\mathrm{CH}_{4}$ por fermentación entérica el Tier I considera niveles de actividad y factores de emisión por cabeza (FE); los primeros provienen de datos de inventarios ganaderos $y$ change. On an international level, GHG inventories measure progress made by different countries in reducing emissions in production sectors. In 2010, Mexico's GHG emissions totaled $748,252 \mathrm{Gg}$ carbon dioxide equivalents $-1 \mathrm{Gg}$ is equal to $10^{9} \mathrm{~g}(1)$. The overall mass of gas emitted into the atmosphere and the radiative forcing effect of each GHG in this mass determines the importance of greenhouse gases such as $\mathrm{CO}_{2}, \mathrm{CH}_{4}, \mathrm{~N}_{2} \mathrm{O}$, and $\mathrm{O}_{3}$, among others. Methane $\left(\mathrm{CH}_{4}\right)$ deserves particular attention among the GHG because its radiative forcing effect is 25 to 34 times greater than that of $\mathrm{CO}_{2}$, that is, $1 \mathrm{~g} \mathrm{CH}_{4}$ equals at least $25 \mathrm{~g}$ $\mathrm{Ceq}(2)$.

The role of livestock production in GHG emissions is actively debated, but clearly significant $(3,4,5)$. In Mexico, for example, total $\mathrm{CH}_{4}$ emissions from enteric fermentation accounted for $20.1 \%$ methane emissions while fugitive emissions from petroleum production represented most of the remainder(6). Enteric and manure-related $\mathrm{CH}_{4}$ is responsible for 75 to $95 \%$ of total GHG emissions at dairy farms in 38 countries(7). Worldwide, Mexico was in eleventh place as far as enteric $\mathrm{CH}_{4}$ emissions $(22,244 \mathrm{Gg})$ in $1998(8)$. By 2010, however, emission from enteric fermentation was 37,961 $\mathrm{Gg} \mathrm{Ceq}$ and that from feces management was $7,553 \mathrm{Gg}$ Ceq, which together accounted for almost half the $92,184 \mathrm{Gg}$ Ceq total $\mathrm{CH}_{4}$ emissions from the agricultural sector(1). However, other studies have generated disparate figures for the total amount of $\mathrm{CH}_{4}$ emitted. One study reported emissions of $144,000 \mathrm{Gg}$ $\mathrm{CH}_{4}$ in 1970 and 270,000 Gg CH 4 in 2010 for the dairy sector in Mexico(9), whereas another study reported emissions in 1995 to have been $285 \mathrm{Gg} \mathrm{CH} \mathrm{CH}_{4}(10)$. This wide range of figures highlights the need to reduce uncertainty in emissions estimations by studying emission factors and intensities.

Signatory countries of the United Nations Framework Convention on Climate Change (UNFCCC) agreed to annually report GHG emission inventories following Intergovernmental 
los segundos de valores por defecto especificados para regiones continentales y sistemas productivos. La emisión de $\mathrm{CH}_{4}$ resulta de la multiplicación del nivel de actividad por el FE. En el Tier II el FE se calcula a partir del consumo de energía neta para mantenimiento, actividad, crecimiento, gestación y lactación. El Tier III determina el FE mediante metodologías de medición directa de la emisión de GEI.

La metodología del IPCC basada en el cálculo por cabeza del FE (Tier I) desfavorece a la productividad como estrategia de mitigación; en tanto las emisiones de GEI por unidad de producto disminuyen conforme aumenta la productividad(12). La intensidad de emisión varía entre productores dada las diferentes condiciones agroecológicas, prácticas de pastoreo o estabulación, alimentación y alimentos. El concepto de intensidad de emisión es útil para valorar las estrategias de mitigación en el sistema productivo y para guiar los patrones de consumo de alimentos por la sociedad(13).

Existen datos que no se usan en la generación de inventarios de GEI, pero integrarlos en el cálculo del inventario tiene mejor relación costo beneficio en comparación a: efectuar experimentos, diseñar nuevos procedimientos de medición o modificar las metodologías o ecuaciones existentes; una base de datos de este tipo es la mantenida por la Asociación Holstein de México (AHM) al recopilar, procesar, certificar y difundir información de los hatos lecheros. La AHM genera indicadores productivos para el mejoramiento genético del ganado y conserva datos genealógicos de la producción de vacas Holstein-Friesian; suficientes para calcular la emisión de $\mathrm{CH}_{4}$ por fermentación entérica usando el Tier II. Por tanto, el objetivo de este estudio fue calcular la emisión de $\mathrm{CH}_{4}$ entérico para la lactancia y el periodo seco con datos del año 2007 en Querétaro. Este año concuerda con el Censo Agrícola, Ganadero y Forestal del 2007 producido por el Instituto Nacional de Estadística y Geografía (INEGI). Se usó el Tier II y los datos proporcionados por la
Panel on Climate Change (IPCC) guidelines, using either of three Tier or precision levels(11). For $\mathrm{CH}_{4}$ emissions originating in enteric fermentation, Tier I considers activity levels and emission factors (EF) per head of livestock; the former are taken from livestock inventory data and the latter from default values specified for continental regions and productive systems. The $\mathrm{CH}_{4}$ emissions level is then calculated by multiplying the activity level by the EF. In Tier II, the EF are calculated from net energy intake for maintenance, activity, growth, gestation and lactation. Tier III determines the EF using direct GHG emissions measurement methodologies.

The Tier I methodology, based on calculation of EF per head, discourages changes in productivity as a mitigation strategy while GHG emissions per product unit decrease as productivity increases(12). Emission intensity varies among producers in response to agroecological conditions, grazing and rearing practices, feed regimes and feed type. The concept of emission intensity is useful in evaluating mitigation strategies at the productive system level and for guiding feed intake patterns(13).

Some data are not normally used in GHG inventory generation. Integrating them into inventory calculation can improve the cost:benefit ratio of inventory generation compared to other options such as running experiments, designing new measurement procedures or modifying existing methodologies or equations. For dairy herds in Mexico, an excellent source of this type of data is maintained by the Holstein Association of Mexico (Asociación Holstein de México - AHM), which collects, processes, certifies and publishes data on registered dairy herds. The AHM generates production indicators aimed at improving cattle genetics and archives genealogical data for production in Holstein-Friesian cows. These records are sufficient to allow calculation of enteric fermentation $\mathrm{CH}_{4}$ emissions using the Tier II methodology. 
AHM para representar hatos del sistema intensivo de producción lechera en estabulación en Querétaro.

\section{MATERIAL Y MÉTODOS}

Los registros de lactancia consistieron en identificación del hato y de la vaca, fecha de nacimiento, fecha de parto, número de lactancia, fecha de fin de lactancia, fecha de medición del pesaje de leche, kilogramos de leche en la fecha de medición, porcentaje de grasa y proteína en el pesaje. El laboratorio de la AHM es certificado por Quality Certification Services Inc. y efectúa la medición de grasa y proteína con un analizador infrarrojo medio modelo Bentley 2000 (Bentley Instruments Inc., USA). Los registros tuvieron hasta diez fechas de pesaje, a un intervalo promedio de 33 días (d). Se usaron 11,092 registros; considerándose sólo lactancias con al menos un día de lactancia en el 2007 y lactancias mayores a $100 \mathrm{~d}$ y menores a $500 \mathrm{~d}$. Al limitar el análisis a lactancias con 500 d se logra un compromiso razonable entre vacas con lactaciones de 305 d y vacas con lactancias más largas, pues sólo $5 \%$ de las vacas lactan más de $500 \mathrm{~d}(14)$, pero $55 \%$ lactan más de $305 \mathrm{~d}(15)$.

El rendimiento de leche determina una proporción importante de las necesidades de energía de la vaca, también la cantidad de leche diaria varía durante la lactancia y el número de lactancia. Se ha observado que la función gamma incompleta representa en forma adecuada la curva de lactancia caracterizada por una fase ascendente, un pico y un declive gradual(16); esta función tiene igual o menor varianza del error en comparación con otras funciones (Gaines, Rook, Dijkstra o Pollott) representativas de la curva de lactancia en hatos del centro de México(17). Considerando la relativa habilidad predictiva de modelos complejos de la curva de lactancia, se recomienda usar modelos como la función gama incompleta, a menos de necesitarse detalles mecanísticos de curva de lactancias extendidas $>800 \mathrm{~d}(15)$. La función utilizada es:
The objective of the present study was to calculate the enteric $\mathrm{CH}_{4}$ emissions for lactation and dry periods of dairy cows using data from 2007 in the state of Querétaro, Mexico. In this same year, the National Institute of Statistics, Geography and Data Processing (Instituto Nacional de Estadística, Geografía e Informática - INEGI) conducted the Agricultural, Livestock and Forestry Census. The Tier II methodology was applied using AHM data representing confined, intensive system dairy herds in the state of Querétaro, Mexico.

\section{MATERIAL AND METHODS}

The lactation data used in the calculations included herd and cow identification; date of birth; calving date; lactation number; lactation end date; milk yield $(\mathrm{kg})$ and weighing date; and milk fat and protein percentage. The AHM laboratory is certified by Quality Certification Services Inc. and runs fat and protein measurements using a mid infrared analyzer (Bentley 2000, Bentley Instruments Inc., USA). Each lactation record contained up to ten weighing dates at an average interval of $33 \mathrm{~d}$. A total of 11,092 records were used in the analysis, including those with at least one lactation day in 2007, lactations longer than $100 \mathrm{~d}$ and shorter than $500 \mathrm{~d}$. Limiting the analysis to lactations of less than $500 \mathrm{~d}$ results in a reasonable compromise between cows with lactations of $305 \mathrm{~d}$ and those with longer lactations, as only $5 \%$ of cows lactate longer than $500 \mathrm{~d}(14)$, but $55 \%$ lactate for more than $305 \mathrm{~d}(15)$.

Milk yield determines a significant proportion of a cow's energy requirements; daily milk yield can vary during lactation and by lactation number. The incomplete gamma function adequately represents the lactation curve characterized by an ascending phase, a peak and a gradual decline(16); indeed, it has an error variance equal to or less than other formulas (e.g. Gaines, Rook, Dijkstra or Pollott) used to represent lactation curves in herds in central Mexico(17). Given the relative predictive 
$\mathrm{Y}_{t}=\mathrm{a} \cdot \mathrm{t}^{\mathrm{b}} \cdot e^{-\mathrm{ct}}$

Donde $Y_{t}$ es la producción de leche en el t-ésimo día de lactancia; $e$ es la base de los logaritmos naturales; $a, b$, c son los parámetros que definen las curvas a ajustar. El rendimiento inicial inmediatamente después del parto se representa por $a ; b$ es la tasa de cambio desde la producción inicial hasta el máximo rendimiento; $c$ es la tasa de cambio desde el máximo rendimiento hasta el final de la lactancia. La persistencia $(s)$, definida como el grado con el que se mantiene el pico de producción de leche, se calculó como " $(b+1) \cdot \ln (c)$ "; la producción de leche por lactancia a $305 \mathrm{~d}(\mathrm{Y})$ se obtuvo como la sumatoria de $Y_{t}$ hasta el día 305; el máximo rendimiento de leche $\left(Y_{\max }\right)$ se calculó con la expresión $a \cdot(b / c)^{b} \cdot e^{-b} ;$ y la media de los días en leche (DL), como el promedio de cada lactancia.

El modelo de curva de lactancia se determinó usando "Table Curve 2D" (Systat Software Inc.) y verificando la significancia de la prueba $F$ para el error por bondad de ajuste, la normalidad y varianza homogénea de los residuales; sólo se consideraron los modelos significativos que cumplieran los supuestos de normalidad y homocedasticidad. La independencia en los residuales se confirmó con la función de auto-correlación hasta el orden 10 y prueba de $t$ usando Minitab v 16 (Minitab Inc.). Las variables modeladas fueron rendimiento de leche $\left(Y_{t}\right)$ y porcentaje de grasa $\left(G_{t}\right)$. Las vacas de cada hato fueron submuestras y los hatos las observaciones; para poder inferir sobre los hatos, poder verificar la bondad de ajuste y considerando al hato como una condición de manejo característico de cada grupo de animales. Las repeticiones fueron $n=$ $16,17,16,16,13,14$ para la primera a sexta lactancia (L1 a L6). La sexta lactancia contempló los registros de seis o más lactancias. Las medias de los estimadores de los parámetros de la función gamma incompleta, $\mathrm{DL}, s, \mathrm{Y}, \mathrm{Y}_{\max }$ y el pico de producción se compararon con la prueba Tukey-Kramer para modelos desbalanceados(18) y siendo la variable explicativa el número de capacity of complex lactation curve models, those like the incomplete gamma function are recommended, unless mechanistic details are needed for extended lactation curves ( $>800$ d)(15). The formula used here was:

$\mathrm{Y}_{t}=\mathrm{a} \cdot \mathrm{t}^{\mathrm{b}} \cdot e^{-\mathrm{ct}}$

where $Y_{t}$ is milk yield on the th day of lactation; $e$ is the base of the natural logarithms; and $a$, $b$ and $c$ are the parameters defining the curves to fit. Yield immediately after calving is represented by $a$; the rate of change from initial production to maximum yield is $b$; and $c$ is the rate of change from maximum yield to end of lactation. Persistence $(s)$ is defined as the point at which peak milk yield is maintained; it is calculated as " $(b+1) \cdot \ln (c)$ ". Milk yield per $305 \mathrm{~d}$ lactation $(Y)$ was calculated as the sum of $Y_{t}$ to d 305. Maximum milk yield $\left(Y_{\max }\right)$ was determined with the formula $a \cdot(b / c)^{b} \cdot e^{-b}$, and mean duration of lactation (DL) was the average number of days in each lactation.

The lactation curve model was generated using the package Table Curve 2D (Systat Inc.). Significance was confirmed with the $F$ test for goodness of fit error, normality and homogeneous variance of residuals. Only significant models that met the assumptions of normality and homoscedasticity were considered in the analysis. Residuals independence was confirmed with the autocorrelation function to the $10^{\text {th }}$ order, and a $t$-test using the Minitab v. 16 pacakege (Minitab Inc.). Modeled variables were milk yield $\left(Y_{t}\right)$ and fat percentage $\left(G_{t}\right)$. Cows within each herd were subsamples, while each herd was a replicate. This structure allowed us to infer about the herds, and confirm goodness of fit considering the herd as a characteristic management condition of each group of animals. Repetitions were $n=16,17$, $16,16,13,14$ for the first to the sixth lactation ( $L 1$ to $L 6)$. The sixth lactation included records for cows with six or more lactations. Parameter estimator means for the incomplete gamma function, $\mathrm{DL}, s, \mathrm{Y}, \mathrm{Y}_{\max }$ and peak production were compared with a Tukey-Kramer test for 
lactancia. También se probó el contraste entre vacas primíparas y multíparas. En todas las hipótesis la confianza fue de $95 \%$. Los procedimientos se efectuaron con el Paquete JMP v7 (SAS Institute Inc.).

La emisión de $\mathrm{CH}_{4}$ para cada hato y parto se calculó usando el Tier II(11). La emisión de $\mathrm{CH}_{4}$ procedente de la fermentación entérica se calculó en términos del contenido de energía bruta (EB) y la conversión de energía a metano $\left(\mathrm{Y}_{\mathrm{m}}\right)$. La única propiedad del alimento considerada es la digestibilidad de la energía:

\section{Emisiones $=\mathrm{FE} \cdot$ Población}

Donde: Emisiones es la liberación de $\mathrm{CH}_{4}$ procedente de la fermentación entérica $\mathrm{kg} \mathrm{CH}_{4}$ año-1); FE es el factor de emisión correspondiente a una población específica $(\mathrm{kg}$ $\mathrm{CH}_{4}$ vaca-1 año-1) y Población es el número de vacas. El FE se calcula como:

$$
\mathrm{FE}=\left(\mathrm{EB} \cdot \mathrm{Y}_{\mathrm{m}} \cdot \begin{array}{c}
365 \mathrm{~d} \\
\mathrm{CH}_{4}
\end{array}\right) /\left(\begin{array}{l}
55.65 \mathrm{MJ} / \mathrm{kg} \\
\text { M }
\end{array}\right.
$$

Donde: $Y_{m}$ es la tasa de conversión del $\mathrm{CH}_{4}$ a partir de energía bruta, con valor de 0.06 equivalente a $60 \mathrm{~kJ} \mathrm{MJ-1(11).} \mathrm{No} \mathrm{obstante,} Y_{m}$ puede variar con el nivel de producción de leche y las propiedades de los alimentos; para vacas de alta producción en Alemania $(7,200 \mathrm{~kg} \mathrm{~L}$ vaca $^{-1}$ año-1) se reporta un valor de $61 \mathrm{~kJ}$ $\mathrm{MJ}^{-1}$ (19). Para vacas de alta producción en EE.UU. el Ym fue $5.63 \%$ de la EB(20). La absorción EB en $M J$ vaca-1 $\mathrm{d}^{-1}$ se deriva como la suma de las necesidades de energía neta y las características de digestibilidad de los alimentos:

$$
\mathrm{EB}=\left\{\left[\left(\mathrm{E}_{\mathrm{m}}+\mathrm{E}_{\mathrm{a}}+\mathrm{E}_{\mathrm{L}}+\mathrm{E}_{\mathrm{p}}\right) /\left(\mathrm{E}_{\mathrm{ma}} / \mathrm{ED}\right)\right]\right\}
$$

La energía neta de mantenimiento $\left(E_{m}\right)$, en MJ d-1 es:

$$
\mathrm{E}_{\mathrm{m}}=\mathrm{Cf}_{\mathrm{i}} \cdot(\text { peso })^{0.75}
$$

Donde: $\mathrm{Cf}_{\mathrm{i}}=0.335$, según los coeficientes para el cálculo de la $E_{m}{ }^{(11)}$.

Para fines del cálculo de la $E_{m}$, se estimó el peso correspondiente a las lactancias 1,2 y 3 imbalanced models(18), with lactation number as the explanatory variable. The contrast between primiparous and multiparous cows was also tested. The confidence level in all analyses was $95 \%$ and analyses were run with the JMP v7 package (SAS Institute Inc.).

Methane $\left(\mathrm{CH}_{4}\right)$ emissions were calculated for each herd and lactation number using the Tier II methodology(11). Emissions from enteric fermentation were calculated in terms of gross energy (GE) content and the conversion rate of energy to methane $\left(\mathrm{Y}_{\mathrm{m}}\right)$. The only feed property considered was energy digestibility:

$$
\text { Emissions }=\mathrm{EF} \cdot \text { Population }
$$

Where Emissions is the release of $\mathrm{CH}_{4}$ from enteric fermentation $\left(\mathrm{kg} \mathrm{CH}_{4} \mathrm{yr}^{-1}\right)$; $\mathrm{EF}$ is the emission factors corresponding to a specific population ( $\left.\mathrm{kg} \mathrm{CH}_{4} \mathrm{COW}^{-1} \mathrm{yr}^{-1}\right)$; and Population is the number of cows. The EF is calculated as:

$$
E F=\left(G E \cdot Y_{m} \cdot \begin{array}{c}
365 d) /(55.65 \mathrm{MJ} / \mathrm{kg} \\
\left.\mathrm{CH}_{4}\right)
\end{array}\right.
$$

Where $Y_{m}$ is the $\mathrm{CH}_{4}$ conversion rate from GE with a value of 0.06 equivalent to $60 \mathrm{~kJ} \mathrm{MJ-1(11).}$ However, $Y_{m}$ can vary in response to milk yield and feed properties. For example, $Y_{m}$ is $61 \mathrm{~kJ}$ $\mathrm{MJ}^{-1}$ in high yielding cows $\left(7,200 \mathrm{~kg} \mathrm{~L} \mathrm{cow}^{-1} \mathrm{yr}^{-}\right.$ 1 ) in Germany(19), and in high-yield cows in the United States $Y_{m}$ was $5.63 \%$ of $\mathrm{GE}^{(20) \text {. }}$ Absorption of GE in $M J$ cow $^{-1} \mathrm{~d}^{-1}$ is derived from the sum of net energy needs and feed digestibility characteristics $(D E=$ digestible energy, etc.):

$$
\mathrm{GE}=\left\{\left[\left(\mathrm{E}_{\mathrm{m}}+\mathrm{E}_{\mathrm{a}}+\mathrm{E}_{\mathrm{L}}+\mathrm{E}_{\mathrm{p}}\right) /\left(\mathrm{E}_{\mathrm{ma}} / \mathrm{DE}\right)\right]\right\}
$$

Net maintenance energy $\left(E_{m}\right)$ in $M J d^{-1}$ is:

$$
\mathrm{E}_{\mathrm{m}}=\mathrm{Cf}_{\mathrm{i}} \cdot(\text { weight})^{0.75}
$$

Where $\mathrm{Cf}_{\mathrm{i}}=0.335$, based on the coefficients for calculating $E_{m}{ }^{(11)}$. For the purpose of calculating $E_{m}$, the body weight corresponding to $L 1, L 2$ and L3 were calculated from a sample of 165 cows from eleven corrals. The resulting averages 
con un muestreo de 165 vacas en 11 establos, los promedios fueron: 526, 590 y $640 \mathrm{~kg}$; para las lactancias primera a tercera; para las lactancias 4, 5 y 6 se usó un peso de $680 \mathrm{~kg}$ representativo de vacas de talla grande(21).

La energía neta para la síntesis de leche $\left(E_{L}\right)$, en $\mathrm{MJ} \mathrm{d}^{-1}$ es:

$$
E_{L}=Y_{t} \cdot\left(1.47+0.40 \cdot G_{t}\right)
$$

La energía neta para la preñez $E_{p}$ en $M J d^{-1}$ es:

$$
E_{p}=C_{p} \cdot E_{m}
$$

Donde: $C_{p}=0.10$, correspondiente al coeficiente de preñez.

La relación entre la energía de mantenimiento presente en una dieta y la energía digestible consumida ( $\left.E_{\mathrm{ma}} / \mathrm{ED}\right)$, en $M J \mathrm{~d}^{-1}$ es:

$$
\begin{gathered}
\mathrm{E}_{\mathrm{ma}} / \mathrm{ED}=1.123-\left(4.092 \cdot 10^{-3} \cdot \mathrm{ED}\right)+ \\
{\left[1.126 \cdot 10^{-5} \cdot(\mathrm{ED})^{2}\right]-(25.4 / E D)}
\end{gathered}
$$

La concentración de energía en el alimento expresada como energía digestible (ED) se calculó en Mcal $\mathrm{kg}^{-1}$ y convertida a $\mathrm{MJ} \mathrm{kg}^{-1}$ es(21):

$$
\mathrm{ED}=0.1847371 \cdot \mathrm{NDT}(\%)
$$

Donde: NDT son los nutrimentos digestibles totales, igual al $68 \%$ en la dieta de vacas de alta producción, talla grande y peso promedio de $680 \mathrm{~kg}$ y descontando $3 \%$ por reducción en la eficiencia en la digestión en el valor del NDT al alimentar a un nivel tres veces el mantenimiento(21). El valor usado de ED, 12.56 MJ $\mathrm{kg}^{-1}$, es similar al valor por defecto para la concentración de energía de $18.45 \mathrm{MJ} \mathrm{kg}^{-1}$ de EB(22). Para todas las lactancias se usó un valor único para la concentración de energía. Así mismo, no se consideraron los cambios de peso vivo durante la lactancia.

Se calculó la emisión de $\mathrm{CH}_{4}$ diaria hasta el día 305 para tener un FE comparable al rendimiento ajustado a $305 \mathrm{~d}(\mathrm{Y})$ y también hasta los de $\mathrm{DL}$ para obtener el FE durante la lactancia. La intensidad de emisión por unidad producida (IE, $\mathrm{CH}_{4} \mathrm{~kg}^{-1}$ de leche) se calculó por lactancia y were $526 \mathrm{~kg}$ for $\mathrm{L} 1,590 \mathrm{~kg}$ for $\mathrm{L} 2$ and $640 \mathrm{~kg}$ for L3; the weight $680 \mathrm{~kg}$ was used for lactations 4, 5 and 6 since it represents large cows(21).

Net energy for milk synthesis $\left(E_{M}\right)$, in $M J d^{-1}$, is:

$$
E_{m}=Y_{t} \cdot\left(1.47+0.40 \cdot G_{t}\right)
$$

Net energy for pregnancy $\left(E_{p}\right)$, in $M J d^{-1}$ is:

$$
E_{p}=C_{p} \cdot E_{m}
$$

where $C_{p}=0.10$, which is the pregnancy coefficient.

The ratio between maintenance energy in a diet and digestible energy (DE) intake $\left(E_{\mathrm{ma}} /\right.$ $D E)$, in $M J d^{-1}$ is:

$$
\begin{gathered}
\mathrm{E}_{\mathrm{ma}} / \mathrm{DE}=1.123-\left(4.092 \cdot 10^{-3} \cdot \mathrm{DE}\right)+ \\
{\left[1.126 \cdot 10^{-5} \cdot(\mathrm{DE})^{2}\right]-(25.4 / \mathrm{DE})}
\end{gathered}
$$

Feed energy concentration was expressed as digestible energy (DE), calculated in Mcal $\mathrm{kg}^{-1}$ and converted to $\mathrm{MJ} \mathrm{kg}^{-1(21)}$ :

$$
\mathrm{DE}=0.1847371 \cdot \operatorname{TDN}(\%)
$$

Where TDN is total digestible nutrients. This is equal to $68 \%$ of TDN in the diet of high-yield, large (average weight $=680 \mathrm{~kg}$ ) cows, and includes a $3 \%$ reduction in digestion efficiency in the TDN value when feeding at three times the maintenance level(21). The $12.56 \mathrm{MJ} \mathrm{kg}-1$ value used for $D E$ is similar to the $18.45 \mathrm{MJ}$ $\mathrm{kg}^{-1}$ default value for GE concentration(22). Only one energy concentration value was used for all lactations, and changes in live weight during lactation were not considered. Daily $\mathrm{CH}_{4}$ emissions were calculated up to d 305 to generate an EF comparable to the $305 \mathrm{~d}$ adjusted yield $(\mathrm{Y})$, and also until the total $\mathrm{DL}$ to obtain the $\mathrm{EF}$ during lactation. Emission intensity per unit produced ( $\mathrm{EI}, \mathrm{CH}_{4} \mathrm{~kg}^{-1}$ milk) was calculated per lactation by adding the $\mathrm{CH}_{4}$ produced in all the herds during all the lactation days and dividing the result by the number of lactating cows on said days. This figure was divided by average milk yield in the lactation period. 
Cuadro 1. Medias de los parámetros $a, b$ y $c$ de la función gamma incompleta Table 1. Means of parameters $a, b$ and $c$ of the incomplete gamma function

\begin{tabular}{|c|c|c|c|c|c|c|c|}
\hline \multirow[b]{2}{*}{ Lactation } & \multicolumn{3}{|c|}{ Milk } & \multicolumn{4}{|c|}{ Fat } \\
\hline & $a$ & $b$ & $c \times 10^{-4}$ & $s$ & $a$ & $b$ & $c \times 10^{-4}$ \\
\hline 1 & $14.7^{a}$ & $0.236^{a}$ & $2.42^{a}$ & $7.5^{a}$ & $50.8 \mathrm{a}$ & $0.110^{a}$ & $10.004^{a}$ \\
\hline 2 & $30.9^{b}$ & $0.032^{b}$ & $0.39 a$ & $8.3^{a}$ & $36.7^{a b}$ & $0.021^{a b}$ & $1.762^{b}$ \\
\hline 3 & $31.5^{b}$ & $0.055^{b}$ & $1.55^{a}$ & $8.1^{a}$ & $39.8^{a b}$ & $0.040^{a b}$ & $3.395^{a b}$ \\
\hline 4 & $24.8^{a b}$ & $0.132^{\mathrm{ab}}$ & $2.67^{a}$ & $7.6^{\mathrm{a}}$ & $34.6^{b}$ & $0.002^{b}$ & $1.361^{b}$ \\
\hline 5 & $30.5^{b}$ & $0.116^{a b}$ & $1.56^{\mathrm{a}}$ & $7.9^{a}$ & $31.0^{b}$ & $0.046^{b}$ & $2.117^{b}$ \\
\hline $6+$ & $27.6^{b}$ & $0.089 \mathrm{~b}$ & $2.05^{a}$ & $7.7^{a}$ & $39.8 \mathrm{ab}$ & $0.010^{b}$ & $0.591 b$ \\
\hline SE & 2.9 & 0.039 & 2.43 & 3.0 & 3.9 & 0.024 & 1.9 \\
\hline
\end{tabular}

ab Different letters in the same column indicate difference $(P<0.05)$.

$\mathrm{SE}=$ Standard error.

sumando la cantidad de $\mathrm{CH}_{4}$ producida por todos los hatos durante todos los días de lactancia y dividiendo entre la cantidad de vacas en lactancia en dichos días. El resultado se dividió entre el promedio de kilogramos de leche producido en el periodo de lactancia.

\section{RESULTADOS Y DISCUSIÓN}

Las medias de los parámetros de las curvas de lactancia indicaron diferencias entre los números de lactancia (Cuadro 1). Para la producción del leche el contraste entre la primíparas y multíparas indicó diferencias en los parámetros $a$ y $b$ de la función gama incompleta $(P<0.0001), s(P=0.05)$ y $Y \max (P=0.017)$, pero no hubo diferencia para $C, D L$ O Y. La persistencia $(s)$ de las lactancias fue alta debido a que la tasa de descenso de la producción después de Ymax fue baja, generando curvas relativamente planas. En hatos lecheros intensivos los parámetros $a$ y $b$ son diferentes entre la primera, segunda y tercer lactancia(17). El análisis de la variabilidad estacional, de las condiciones de manejo de los hatos o genotipo podría explicar mejor la variación en la base de datos.

El número de lactancias modeladas fue mayor para L1 y después el número de registros disminuyó (Cuadro 2); esta conformación de la

\section{RESULTS AND DISCUSSION}

Means of the lactation curve parameters were different between lactation numbers (Table 1). In terms of milk yield, differences were found between primiparous and multiparous cows in the $a$ and $b$ parameters of the incomplete gamma function $(P<0.0001), s(P=0.05)$ and Ymax $(P=0.017)$; no differences were present for $c$, DL or Y. Lactation persistence $(s)$ was high due to a low rate of decrease in production after Ymax which generated relatively flat curves. In intensive system dairy herds, the $a$ and $b$ parameters differ between the first, second and third lactations(17). These variations are probably better explained through analysis of seasonal variability, herd management conditions or genotype.

The number of modeled lactations was highest for L1 and then decreased thereafter (Table 2); this is probably an artifact of the voluntary early culling typical of intensive production dairy herds $(15,23)$. The incomplete gamma function represented most $(89.8 \%)$ of the studied lactations, but all the $\mathrm{L} 1$ and $\mathrm{L} 2$ lactations had good fit $(P<0.05)$. Lack of fit appeared when records were incomplete, or when the number of records increased as lactation number progressed in some herds. In contrast, the models were not significant when the curve 
base de datos se consideró un reflejo del desecho voluntario temprano característico de los hatos lecheros en producción intensiva $(15,23)$. El $89.8 \%$ de las lactancias examinadas se representó con la función gama incompleta; pero todas las lactancias de $\mathrm{L} 1$ y $\mathrm{L} 2$ tuvieron buen ajuste $(P<0.05)$. La falta de ajuste se observó cuando los registros de lactancia fueron incompletos o porque disminuyó el número de registros conforme aumentó el número de lactancia en algunos hatos. Por otra parte, los modelos no fueron significativos cuando la curva tuvo una forma plana y los valores de $b$ y $c$ fueron cercanos a cero (Cuadro 1). La capacidad de la función gama incompleta para representar L1 o L2 fue acorde al reporte para hatos lecheros del centro de México, donde se logró un buen ajuste con esta función para primera, segunda y tercer lactancia(17).

La DL promedio (365 d), indicó la presencia de lactancias extendidas en la base de datos analizada (Cuadro 2). Las lactancias extendidas es una estrategia de manejo que capitaliza en alta persistencia de la lactancia y producción económicamente rentable hacia el final de la lactancia; no obstante, la lactancia extendida también es consecuencia de la falla reproductiva(15). was flat and the $b$ and $c$ values were near zero (Table 1 ). The capacity of the incomplete gamma function to represent L1 or L2 agreed with reports for dairy herds in central Mexico in which a good fit was attained using this formula for the first, second and third lactations(17).

The long average DL (365 d) indicates the presence of extended lactations in the analyzed database (Table 2). Use of extended lactations is a management strategy that capitalizing on high lactation persistence and the financially profitable yield towards the end of a lactation; however, it can also be a consequence of reproductive failure(15). Extended and induced lactations are common in Mexican dairy herds, and are maintained by using bovine somatotropin(23). This is important to consider when calculating the annual GHG emissions inventory for a state or country since methane emissions will be greater in the absence of a dry period in any given year.

Values for 305 d milk yield $(Y)$ were similar between the analyzed lactations despite differences identified between the $a$ and $b$ estimates. Average $\mathrm{Y}$ was $9,985 \mathrm{~kg}$ in the database modeled with the incomplete gamma

Cuadro 2. Características de la base de datos y medias de producción: $Y$ es el rendimiento a $305 d, Y_{\max }$ es el rendimiento al pico de lactancia y DL, es la duración de la lactancia

Table 2. Herd and mean production data: $Y$ is yield at $305 \mathrm{~d} ; Y_{\max }$ is yield at lactation peak; and $\mathrm{DL}$ is duration of lactation

\begin{tabular}{lccccc}
\hline Lactation & Herds & Records & $\begin{array}{c}Y \\
(\mathrm{~kg} \text { milk })\end{array}$ & $\begin{array}{c}Y_{\max } \\
(\mathrm{kg} \mathrm{milk})\end{array}$ & $\begin{array}{c}\mathrm{DL} \\
(\mathrm{d})\end{array}$ \\
\hline 1 & 16 & 4622 & $9437^{\mathrm{a}}$ & $34.0^{\mathrm{a}}$ & $366^{\mathrm{a}}$ \\
2 & 17 & 2939 & $10468^{\mathrm{a}}$ & $35.1^{\mathrm{a}}$ & $362^{\mathrm{a}}$ \\
3 & 16 & 1200 & $10359^{\mathrm{a}}$ & $34.8^{\mathrm{a}}$ & $362^{\mathrm{a}}$ \\
4 & 16 & 696 & $9881^{\mathrm{a}}$ & $35.0^{\mathrm{a}}$ & $368^{\mathrm{a}}$ \\
5 & 13 & 314 & $11047^{\mathrm{a}}$ & $38.6^{\mathrm{a}}$ & $364^{\mathrm{a}}$ \\
$6+$ & 14 & 194 & $10016^{\mathrm{a}}$ & $35.4^{\mathrm{a}}$ & $372^{\mathrm{a}}$ \\
SE & & & 725 & 2.0 & 21 \\
\hline
\end{tabular}

ab Different letters in the same column indicate difference $(P<0.05)$.

$\mathrm{SE}=$ Standard error. 
En hatos mexicanos, las lactancias extendidas y lactancias inducidas son comunes y se mantienen mediante la administración de somatotropina bovina(23). Para calcular el inventario de emisiones de GEI anual en el estado o país, la duración de la lactancia es importante, pues la emisión de metano será mayor al no existir periodo seco en un año dado.

El rendimiento de leche a $305 \mathrm{~d}(\mathrm{Y})$ fue semejante entre las lactancias examinadas a pesar de las diferencias identificadas para los estimados de $a$ y $b$. El promedio de $\mathrm{Y}$ en la base de datos modelada con la función gamma incompleta fue de 9,985 kg. Aunque la variación de $Y$ en la base de datos fue aceptable en términos del coeficiente de variación (28\%); los valores de error estándar deberán tomarse en cuenta en los parámetros de entrada para calcular inventarios de emisiones de metano como parte de la incertidumbre en el cálculo(24). Así, el intervalo de confianza al $95 \%$ para $Y$ fue de 8,550 a $11,419 \mathrm{~kg}$, siendo el resultado de $Y$ diferente a los 7,078 L (7,312 kg corregido a $3.5 \%$ de grasa) reportados para la producción de leche en sistema intensivo en México para empresas de los estados de Aguascalientes, Hidalgo, Guanajuato, Jalisco, Michoacán, Puebla y Querétaro(25).

Considerando $365 \mathrm{~d}$ como promedio de $\mathrm{DL}$, el intervalo de confianza al $95 \%$ para el function. In terms of the variation coefficient, variation in $\mathrm{Y}$ in the database (28\%) was acceptable. However, as part of the uncertainty in the calculations, the standard error values must be included in the input parameters when calculating methane emissions inventories(24). The $95 \%$ confidence interval for $Y$ in the present data ranged from 8,550 to $11,419 \mathrm{~kg}$, which differs from the $7,078 \mathrm{~L}(7,312 \mathrm{~kg}$ corrected to $3.5 \%$ fat) reported for $Y$ in intensive diary production systems in Mexico for operations located in the states of Aguascalientes, Hidalgo, Guanajuato, Jalisco, Michoacán, Puebla and Querétaro(25).

Using the average DL figure of $365 \mathrm{~d}$, the $95 \%$ confidence level was 11,061 to $12,793 \mathrm{~kg}$. These yields are higher than the $6,700 \mathrm{~kg}$ milk yield described in the highest emission factors for dairy cattle using the Tier I methodology: in North America, high yield cows fed on grains and high quality forage have EF of $118 \mathrm{~kg} \mathrm{CH}_{4}$ $\operatorname{cow}^{-1} \mathrm{yr}^{-1}(22)$.

Enteric fermentation EF values differed between primiparous and multiparous cows when the adjustment was made at $305 \mathrm{~d}(P=0.0025)$ to $365 \mathrm{~d}(P=0.0011)$, although emission intensity remained between 17.6 and $18.6 \mathrm{~g} \mathrm{CH}_{4} \mathrm{~kg}$ milk (Table 3). For primiparous and multiparous cows, methane EF differed depending on the milk and fat production curve modeled for each herd and lactation number (Figure 1). Milk yield was

Cuadro 3. Factor de emisión (EF) e intensidad de emisión (EI) de metano entérico por lactancia de acuerdo a su duración ajustada a 365 o 305 días

Table 3. Enteric methane emission factors (EF) and intensity (EI) per lactation based on duration adjustment from 365 or 305 days

\begin{tabular}{|c|c|c|c|c|c|c|c|c|}
\hline & \multicolumn{4}{|c|}{ Lactation 365 days } & \multicolumn{4}{|c|}{ Lactation 305 days } \\
\hline & $\mathrm{EF}$ & SE & $\mathrm{El}$ & SE & EF & SE & $\mathrm{El}$ & SE \\
\hline Lactation & $\mathrm{kg} \mathrm{CH}_{4} \operatorname{cow}^{-1}$ & & $\mathrm{~g} \mathrm{CH}_{4} \mathrm{~kg}^{-1}$ milk & & $\mathrm{kg} \mathrm{CH}_{4} \operatorname{cow}^{-1}$ & & $\mathrm{~g} \mathrm{CH}_{4} \mathrm{~kg}^{-1}$ milk & \\
\hline Primiparous & $201.8^{a}$ & 4.6 & $17.9^{a}$ & 0.3 & $165.7^{a}$ & 3.8 & $17.6^{\mathrm{a}}$ & 0.2 \\
\hline Multiparous & $223.7^{b}$ & 11.0 & $18.8^{a}$ & 1.0 & $181.6^{b}$ & 8.3 & $18.6^{a}$ & 0.9 \\
\hline
\end{tabular}

ab Different letters in the same column indicate difference $(P<0.0025)$.

$\mathrm{SE}=$ Standard error. 
rendimiento de leche fue 11,061 a $12,793 \mathrm{~kg}$. Estos rendimientos de leche son superiores a los 6,700 kg descritos para el factor de emisión más alto para el ganado lechero en el Tier I: región Norte América, vacas de alta producción, alimentadas con granos y forraje de alta calidad tienen un factor de emisión de $118 \mathrm{~kg}$ metano vaca-1 $^{-1}$ ño-1(22).

El factor de emisión por fermentación entérica fue diferente entre primíparas y multíparas cuando se ajustó a $305 \mathrm{~d}(P=0.0025)$ y a $365 \mathrm{~d}$ $(P=0.0011)$, en tanto la intensidad de emisión se mantuvo entre 17.6 a $18.6 \mathrm{~g} \mathrm{CH}_{4} \mathrm{~kg}$ leche (Cuadro 3). El factor de emisión de metano para primíparas y multíparas resultó diferente por la curva de producción de leche y grasa modelada para cada hato y número de lactancia; la Figura 1 presenta la evolución de la emisión durante la lactancia. El rendimiento de leche fue el aspecto importante para describir la emisión de metano en la base de datos analizada, pero la representación se simplificó cuando se expresa como intensidad de emisión por unidad de producto.

El presente estudio contribuyó a caracterizar la producción de leche intensiva en México y the most valuable factor for describing methane emissions in the analyzed database, although its representation was simplified when expressed as emission intensity per production unit.

The present study contributed to characterize the intensive system milk production in Mexico and reducing uncertainty in application of the IPCC Tier II methodology. However, methane conversion factor $(\mathrm{Ym})$, feed digestibility and feed composition values were taken from the literature, following IPCC best practices for inventory generation $(11,22)$. Future research will need to include the wide diversity of management practices and environmental conditions present in any given country. Validation of the enteric $\mathrm{CH}_{4}$ emissions estimates used here could only be by using scaled data for $\mathrm{CH}_{4}$ measurements in individual animals or by disaggregating atmospheric measurements to the farm level by applying gas measurement and turbulent flow systems. Indeed, the Tier II methodology contains greater estimation and systemic errors than do mechanistic models of enteric $\mathrm{CH}_{4}$ emission $(20,26)$. This methodology is intended for reporting regional and country inventories, and does not consider emissions associated with electric energy use, processing,

Figura 1. Emisión entérica de metano para vacas de primera lactancia $(A ; n=16)$ y para vacas multíparas $(B ; n=76)$. Las líneas son la media y su error estándar

Figure 1. Emission of enteric methane in primiparous $(A ; n=16)$ and multiparous cows $(B ; n=76)$. Lines represent the mean and standard error

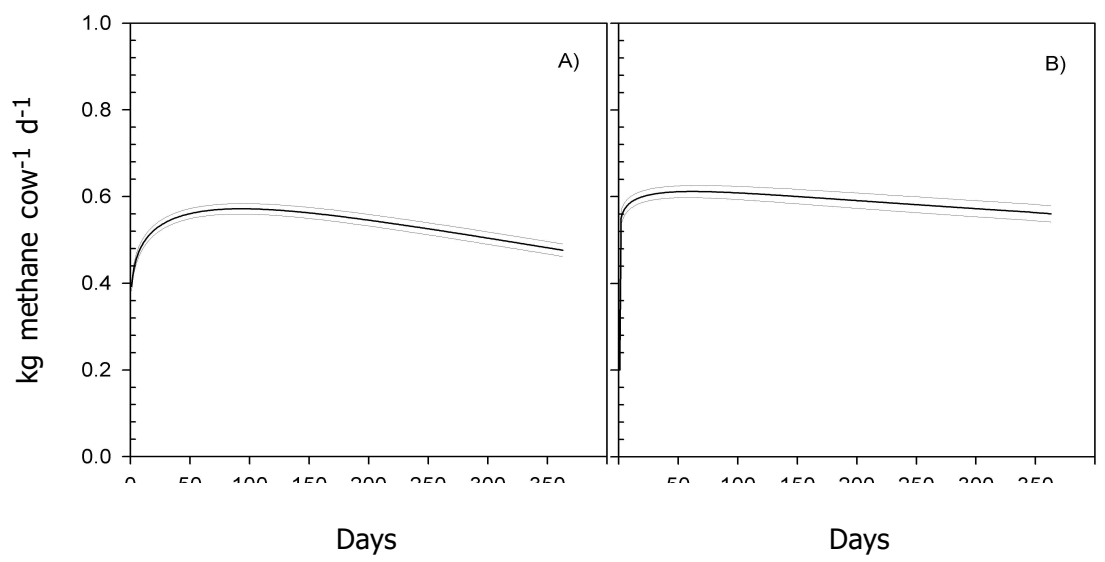


reducir la incertidumbre en la aplicación de la metodología Tier II del IPCC. Sin embargo, para el factor de conversión de metano (Ym), la digestibilidad y composición del alimento fue necesario recurrir a valores reportados en la literatura y de acuerdo a las buenas prácticas del IPCC para la generación de inventarios $(11,22)$. La diversidad en prácticas de manejo y condiciones ambientales deben representarse en la variabilidad de esos factores en futuros estudios. La validación de los estimados de emisión de $\mathrm{CH}_{4}$ entérico obtenidos aquí sólo es posible contando con datos escalados de mediciones de la emisión de $\mathrm{CH}_{4}$ en animales individuales o mediante la desagregación de mediciones atmosféricas a nivel de granja, usando sistemas de medición de gases y flujo turbulento. Más aún, la metodología Tier II del IPCC presenta mayores errores de estimación y sistemáticos en relación a modelos mecanísticos de emisión de $\mathrm{CH}_{4}$ entérico $(20,26)$. La metodología del IPCC está orientada a reportar inventarios de regiones y países y no considera las emisiones asociadas por consumo de energía eléctrica, procesamiento, combustibles, etc. Para la estructura de mercado en México la importación de granos y la movilización de leche líquida son aspectos de importancia. De manera paralela a la aplicación de metodologías del IPCC, los esfuerzos futuros tendrán que generar mediciones directas, comparar modelos mecanísticos y calcular emisiones en los ciclos de vida para los sistemas de producción.

Los factores de emisión e intensidades de emisión reportados en la literatura deben contrastarse considerando las condiciones ambientales, sistemas productivos, manejo del ganado, tipo de modelo usado para estimar la producción de metano, bases de datos disponibles y nivel de profundidad del estudio, entre otros. Así, los resultados de intensidad de emisión (17.6 a $18.6 \mathrm{~g} \mathrm{CH}_{4} \mathrm{~kg}$ leche) se encontraron en la misma escala de magnitud que los reportados para vacas de alto rendimiento: $25 \mathrm{~g} \mathrm{CH}_{4} \mathrm{~L}^{-1}$ leche (fermentación entérica y excretas) para el hato lechero fuels, etc. Grain import and transport of liquid milk are important aspects of the dairy market structure in Mexico. When applied in the future, the IPCC methodologies will need to be paired with direct measurements, comparisons with mechanistic models and calculation of lifecycle emissions for production systems.

The emission factors and intensities reported in the literature need to be compared considering environmental conditions, productive systems, livestock management practices, the methane production estimation model used, available databases and study depth, among other factors. The present emission intensity results (17.6 to $18.6 \mathrm{~g} \mathrm{CH}_{4} \mathrm{~kg}$ milk) were within previously reported ranges for high yield cows: $25 \mathrm{~g} \mathrm{CH}_{4} \mathrm{~L}^{-1}$ milk (enteric fermentation and manure) for the dairy cow population in Mexico(9); 15.4 to $17.6 \mathrm{~g} \mathrm{CH}_{4} \mathrm{~kg}^{-1}$ milk (enteric fermentation) in response to changes in the proportions of grazing to corn silage in the Netherlands(26); and 18.0 to $19.1 \mathrm{CH}_{4} \mathrm{~g} \mathrm{~kg}^{-1}$ in experiments using different proportions of alfalfa and corn silage(27).

The present EF per head results (201 to $223 \mathrm{~kg}$ $\mathrm{CH}_{4}$ cow $^{-1}$ in 365 d) were higher than the average reported in some national inventories: $120.76 \mathrm{~kg}$ in the USA $(28) ; 113 \mathrm{~kg}$ in the Netherlands(29); and 128.8 to $139 \mathrm{~kg}$ in Germany(19). This discrepancy is probably due to the fact that the AHM database does not include all the cows in a herd, since it focuses on high-yield dairy cows and longer lactations (365 vs 305 d). Emission of GHG increases as animal yield rises, but emissions per kilogram of milk corrected for fat content decreases notably as production increases(12). In addition, Tier II uses a fixed $Y_{m}$, which can result in a $12.5 \%$ overestimation in dairy cattle, negatively affecting its accuracy $(19,20)$. Country-level solutions are needed in enteric methane inventories to derive feed composition and properties as a function of animal performance and thus generate more accurate calculations(19). 
mexicano(9); entre 15.4 y $17.6 \mathrm{~g} \mathrm{CH}_{4} \mathrm{~kg}^{-1}$ leche (fermentación entérica) en función de los cambios en la proporción de pastura en pastoreo respecto del ensilaje de maíz en Holanda(26); entre 18.0 y $19.1 \mathrm{CH}_{4} \mathrm{~g} \mathrm{~kg}^{-1}$ en experimentos con proporción de ensilado de alfalfa y maíz(27).

El factor de emisión por cabeza (201 a $223 \mathrm{~kg}$ $\mathrm{CH}_{4}$ vaca-1 en $365 \mathrm{~d}$ ) fue mayor al promedio reportado en inventarios nacionales: $120.76 \mathrm{~kg}$ en EE.UU.(28), $113 \mathrm{~kg}$ en Holanda(29), 128.8 a $139 \mathrm{~kg}$ en Alemania(19). Esto se explicó porque la base de datos de la AHM no considera a todas las vacas de cada hato y representó a vacas de alto rendimiento de leche diario, y también con lactancias más largas 365 vs 305 d. La emisión de gases con efecto invernadero aumenta conforme mayor es el rendimiento animal, pero las emisiones por kilo de leche corregida por grasa declinan sustancialmente conforme la productividad aumenta(12). Además el Tier II indica un valor fijo de $Y_{m}$, que puede resultar en una sobre estimación de $12.5 \%$ para el ganado lechero y ser inadecuado $(19,20)$. Para los esfuerzos de inventarios de metano entérico se necesitan soluciones nacionales para derivar la composición y propiedades del alimento en función del desempeño animal y generar cálculos más precisos(19).

En la literatura se reportan varias estimaciones de la emisión de metano entérico por el ganado aplicando factores de emisión específicos para México. La emisión entérica se representó en función del consumo de energía en el alimento, y éste a su vez, en función de la masa corporal típica de bovinos clasificados por edad y región climática, pero no se consideró el nivel de producción de leche(10). Una modificación al Tier I para el inventario de México tomó en cuenta un ciclo productivo de $305 \mathrm{~d}$ en lactancia y 60 d de periodo seco, una producción promedio de $4,400 \mathrm{~kg}$ por lactancia de una vaca típica de $400 \mathrm{~kg}$ y un modelo de la curva de lactancia(30); sin embargo, el modelo de lactancia seleccionado correspondió al ajuste de
Enteric methane emission estimates for cattle using emission factors specific to Mexico have been done. In these studies, enteric emissions are represented as a function of energy intake in the feed and typical body mass of cattle classified by age and climatic region, but milk production levels are not considered(10). One national inventory applied a modified Tier I methodology using a $305 \mathrm{~d}$ lactation, a $60 \mathrm{~d}$ dry period, a 4,400 $\mathrm{kg}$ average yield per lactation in a typical $400 \mathrm{~kg}$ cow; and a lactation curve model(30). However, this lactation model was obtained from data fitted for yield from 100 Friesian cows in the third lactation from Reading, UK $(31,32)$. Another national inventory used milk yield from FAO reports $(2,800$ to $4,541 \mathrm{~kg}$ milk $\left.\mathrm{cow}^{-1} \mathrm{yr}^{-1}\right)$, milk composition and feed rations taken from previous studies, and assumed that all dairy cows were confined(9).

The historical contribution of methane emissions is significant, but simplifications need to be made in the model so that available databases can be used; for example, averaging the dairy and nondairy cattle emission factors to then multiply it by the cattle population of each country(8). Published studies expose the limitations in the availability and quality of cattle activity and population data, highlighting the need for further research in an effort to adequately quantify how much of GHG emissions originate in the livestock sector $(3,4,5)$. Another challenge is difficulty in data analysis caused by inconsistency among the units used to report GHG emission figures, particularly when SI (Sistème international d'unités) units are not employed. For instance, in one study the units $\mathrm{Gg}\left(10^{9} \mathrm{~g}\right)$ and $M t$ (an abbreviation interpreted as megaton - equivalent to $10^{12} \mathrm{~g}$, or as metric ton equivalent to $10^{6} \mathrm{~g}$ ) are used interchangeably and produce the same methane emission result for dairy cattle in Mexico(9). In another example, worldwide methane concentration from enteric fermentation from 1890-1998 was calculated as $1,183,095 \mathrm{Gg} \mathrm{CH}_{4}(8)$, but the same authors later published the figure of 8 million $\mathrm{Gg}$ Ceq(33) for the same concept. These two figures are not comparable using acceptable values for 
datos de rendimiento de 100 vacas Friesian en su tercera lactancia en Reading, Inglaterra(31,32). Otro inventario nacional consideró la producción de leche de acuerdo a informes de la FAO $(2,800$ a $4,541 \mathrm{~kg}$ de leche vaca-1 año-1); a partir de reportes de experimentos, se obtuvieron datos sobre composición de la leche y las raciones ofrecidas; también se asumió que todas las vacas lecheras se encontraban en estabulación(9).

La contribución histórica de las emisiones de metano es un asunto importante, pero es necesario hacer simplificaciones en el modelo para poder usar las bases de datos disponibles, por ejemplo promediar el factor de emisión del ganado lechero y no lechero para multiplicarse por la población de bovinos de cada país(8). En los estudios citados se manifiestan limitantes en disponibilidad y calidad de los datos de actividad y población, por eso se necesita investigación para dimensionar adecuadamente la responsabilidad del sector pecuario en la emisión de $\operatorname{GEI}(3,4,5)$. Otro problema es la incoherencia en las unidades usadas para reportar las cifras de emisión de GEI, sobre todo cuando no son unidades del sistema internacional de medidas; ocasionando dificultad en interpretación de la información. En otro trabajo, las unidades $\mathrm{Gg}\left(10^{9} \mathrm{~g}\right)$ y Mt (la abreviatura puede interpretarse como mega tonelada equivalente a $10^{12} \mathrm{~g}$, o tonelada métrica equivalente a $10^{6} \mathrm{~g}$ ) se utilizan indistintamente, con el mismo resultado sobre la emisión de metano del ganado lechero de México(9). La concentración de metano por fermentación entérica mundial durante 18901998 se calculó en $1^{\prime} 183,095 \mathrm{Gg} \mathrm{CH}_{4}{ }^{(8)}$, pero después publican los mismos autores el mismo dato como 8 millones $\mathrm{Gg}$ Ceq(33); las cifras no son comparables usando los valores aceptables para conversión de metano en bióxido de carbono equivalente(2). Antes de efectuar el escalamiento para calcular inventarios de GEI es necesario contrastar los factores de emisión o la intensidad de emisión de las clases animales y modelos productivos. conversion of methane into carbon dioxide equivalents(2). Finally, before any attempt at scaling is made to calculate GHG inventories, comparisons will be needed between the emission factors or intensities of different animal classes and productive models.

\section{CONCLUSIONS AND IMPLICATIONS}

Analysis with the incomplete gamma formula and lactation curves showed high-yield dairy cows in Querétaro state to differ between primiparous and multiparous individuals for the studied variables. Average lactation was oneyear (365 d) long. Enteric methane emission during lactation differed between primiparous and multiparous cows, whether at $365 \mathrm{~d}$ or adjusted to 305 d. However, lactation number or duration had no effect on average enteric methane emission intensity per kilogram of milk produced. The uncertainty present in enteric methane emissions inventories can be reduced by incorporating data for milk yield, lactation duration, and herd composition in terms of primiparous and multiparous cows. Milk yield can be represented using the incomplete gamma formula. However, an acceptable simplification would be to multiply average daily milk yield by the number of lactation days. This was shown to be viable in the present study in which relatively flat, highly precise curves were identified for high-yield cows. If enteric methane emission on a dairy farm is assumed to be $75 \%$ of its GHG emissions, and the emission factors are accounted for, then a dairy producer managing more than 2,500 cows would surpass the $25,000 \mathrm{Gg}$ Ceq threshold established in the Rules of the General Climate Change Law for the National Register of Emissions for the Republic of Mexico (Reglamento de la Ley General de Cambio Climático en Materia del Registro Nacional de Emisiones para la República Mexicana - RENE), and the farm would be forced to report its emissions beginning in 2018. In response to applicable laws (e.g. NMX-SAA14064/1-IMNC-2007, NMX-SAA-14064/2-IMNC2007, among others), the Mexican Certification 


\section{CONCLUSIONES E IMPLICACIONES}

Las vacas de alto rendimiento en Querétaro se representaron con la función gama incompleta y las curvas de lactancia fueron distintas para primíparas y multíparas. La lactancia tuvo una duración promedio de un año. La emisión de metano entérico durante la lactancia fue diferente entre vacas primíparas y multíparas, ya fuera hasta los $365 \mathrm{~d}$ o ajustada a $305 \mathrm{~d}$. Sin embargo, el número de lactancia o duración de la lactancia no afectó la intensidad de emisión de metano entérico promedio por kilogramo de leche producida. Los inventarios de emisiones de metano entérico pueden disminuir su incertidumbre, al incorporar datos de rendimiento de leche, duración de la lactancia y composición del hato de acuerdo a primíparas y multíparas. El rendimiento de leche puede representarse con la función gama incompleta; sin embargo, una simplificación aceptable sería usar el promedio de producción diaria multiplicado por los días en leche, debido a que en el presente estudio se encontraron curvas relativamente planas y con alta persistencia para vacas de alto rendimiento de leche. Considerando que una emisión de metano entérico es de $75 \%$ del total de GEI en una granja y los factores de emisión, entonces una empresa lechera mayor a 2,500 vacas posiblemente deba reportar a partir del 2018 obligatoriamente sus emisiones al rebasar el umbral de $25,000 \mathrm{Gg}$ Ceq establecido en el Reglamento de la Ley General de Cambio Climático en Materia del Registro Nacional de Emisiones para la República Mexicana (RENE). La Entidad Mexicana de Acreditación mantiene listados vigentes de los organismos para verificación o validación de emisiones GEI para el RENE según la norma NMX-SAA-14064/1-IMNC-2007, NMX-SAA-14064/ 2-IMNC-2007, entre otras.

\section{AGRADECIMIENTOS}

Este trabajo fue financiado por el fondo CONACYT-SEMARNAT 10873, INE-Gobierno del Estado de Querétaro Anexo 34 2010, INECC
Organization (Entidad Mexicana de Acreditación) maintains current lists of the organizations that implement GHG emissions verification and validation to meet RENE stipulations.

\section{ACKNOWLEDGEMENTS}

The research reported here was financed by the CONACYT-SEMARNAT 10873 fund, INEGobierno del Estado de Querétaro Anexo 34 2010, INECC Convenio INE/PS-051/20. Thanks to the Asociación Holstein de México for access to and use of their database.

End of english version

Convenio INE/PS-051/20. Gracias a la Asociación Holstein de México por las facilidades y el uso de la base de datos.

\section{LITERATURA CITADA}

1. INECC. Instituto Nacional de Ecología y Cambio Climático. México quinta comunicación nacional ante la convención marco de las Naciones Unidas sobre el cambio climático. México, DF, México: Secretaría de Medio Ambiente y Recursos Naturales e Instituto Nacional de Ecología y Cambio Climático. 2012.

2. Shindell TD, Faluvegi G, Koch MD, Schmidt AG, Unger N, Bauer ES. Improved attribution of climate forcing to emissions. Science 2009;326(5953):716-718.

3. FAO. Food and Agriculture Organization of the United Nations. Livestock's long shadow. Rome, Italy: Food and Agriculture Organization of the United Nations; 2006.

4. Glatzle A. Questioning key conclusions of FAO publications 'Livestock's long shadow' (2006) appearing again in 'Tackling climate change through livestock' (2013). Pastor Res Policy Pract 2014;4(1):1-6.

5. Reddy PP. Climate resilient agriculture for ensuring food security. New Delhi, India: Springer; 2015.

6. INE. Instituto Nacional de Ecología. México cuarta comunicación nacional ante la convención marco de las Naciones Unidas sobre el cambio climático. México, DF, México: Secretaría de Medio Ambiente y Recursos Naturales e Instituto Nacional de Ecología. 2009.

7. Hagemann M, Hemme T, Ddambi A, Alqaisi O, Sultana MN. Benchmarking of greenhouse gas emissions of bovine milk 
production systems for 38 countries. Anim Feed Sci Technol 2011;(166-167):46-58.

8. Muylaert de Araujo MS, Pires de Campos C, Pinguelli RL. Historical emissions, by country, of $\mathrm{N}_{2} \mathrm{O}$ from animal manure management and of $\mathrm{CH}_{4}$ from enteric fermentation in domestic livestock. Clim Res 2007;34(3):253-258.

9. Rendón-Huerta JA, Pinos-Rodríguez JM, García López JC, Yáñez-Estrada LG, Kebreab $E$. Trends in greenhouse gas emissions from dairy cattle in Mexico between 1970 and 2010. Anim Prod Sci 2013;54(3):292-298.

10. Ruiz-Suárez LG, González-Avalos E. Modeling methane emissions from cattle in Mexico. Sci Total Environ 1997;206(2-3):177-186.

11. IPCC. Intergovernmental Panel on Climate Change. 2006 IPCC Guidelines for national greenhouse gas inventories. Hayama, Japan: Institute for Global Environmental Strategies. 2006.

12. Gerber $P$, Vellinga $T$, Opio $C$, Steinfeld H. Productivity gains and greenhouse gas emissions intensity in dairy systems. Livestock Sci 2011;139(1-2):100-108.

13. Knapp JR, Laur GL, Vadas PA, Weiss WP, Tricarico JM. Enteric methane in dairy cattle production: Quantifying the opportunities and impact of reducing emissions. J Dairy Sci 2014;97(6):3231-3261.

14. Cole JB, Null DJ, VanRaden PM. Best prediction of yields for long lactations. J Dairy Sci 2009;92(4):1796-1810.

15. Dematawea CMB, Pearson RE, VanRaden PM. Modeling extended lactations of Holsteins. J Dairy Sci 2007;90(8):3924-3936.

16. Wood PDP. Algebraic model of the lactation curve in cattle. Nature 1967;216(5111):164-165.

17. Val-Arreola D, Kebreab E, Dijkstra J, France J. Study of the lactation curve in dairy cattle on farms in central Mexico. J Dairy Sci 2004;87(11):3789-3799.

18. Rafter AJ, Abell LM, Braselton PJ. Multiple comparison methods for means. SIAM Rev 2002;44(2):259-278.

19. Dämmgen U, Rösemann $C$, Haenel HD, Hutchings NJ. Enteric methane emissions from German dairy cows. Landbauforschung - vTI Agric For Res 2012;62(1-2):21-32.

20. Kebreab $E$, Johnson KA, Archibeque $S L$, Pape $D$, Wirth $T$. Model for estimating enteric methane emissions from United States dairy and feedlot cattle. J Anim Sci 2008;86(10):2738-2748.

21. NRC. National Research Council. Nutrient Requirements of Dairy Cattle. 7th ed. Washington, DC, USA: National Academy of Sciences; 2001.

22. IPCC. Intergovernmental Panel on Climate Change. Good practice guidance and uncertainty management in national greenhouse gas inventories. Chapter 4: Agriculture. Hayama, Japan: Institute for Global Environmental Strategies. 2000.

23. Mellado $M$, Antonio-Chirino E, Meza-Herrera C, Veliz FG, Arévalo JR, Mellado J, de Santiago A. Effect of lactation number, year, and season of initiation of lactation on milk yield of cows hormonally induced into lactation and treated with recombinant bovine somatotropin. ] Dairy Sci 2011;94(9):4524-4530.

24. Gentner $D R$, Ford $T B$, Guha A, Boulanger $K$, Brioude J, Angevine WM, et al. Emissions of organic carbon and methane from petroleum and dairy operations in California's San Joaquin Valley. Atmos Chem Phys 2014;14(10):49554978.

25. Mariscal VA, Estrella $H Q$, Ruiz AF, Sagarnaga MV, Salas JMG, González MA, Juárez AZ. La cadena productiva de bovinos lecheros y el TLCAN. En: Avila DJA, et al. editores. Presente y futuro de los sectores ganadero, forestal y de la pesca mexicanos en el contexto del TLCAN. México DF, México: El Colegio de México, Centro de Estudios Económicos Universidad Autónoma Chapingo. 2008.

26. Bannink A, van Schijndel MW, Dijkstra J. A model of enteric fermentation in dairy cows to estimate methane emission for the Dutch National Inventory Report using the IPCC Tier 3 approach. Anim Feed Sci Technol 2011;(166-167):603618.

27. Arndt C, Powell JM, Aguerre MJ, Wattiaux MA. Performance, digestion, nitrogen balance, and emission of manure ammonia, enteric methane, and carbon dioxide in lactating cows fed diets with varying alfalfa silage-to-corn silage ratios. J Dairy Sci 2015;98(1):418-430.

28. EPA. United States Environmental Protection Agency. Inventory of U.S. greenhouse gas emissions and sinks: 19902012. Common reporting format (CRF) tables. USA-2014 2012-v1.1.xls. Table 4.A Sectorial background data for agriculture: enteric fermentation. Washington DC, USA: United States Environmental Protection Agency. 2014.

29. Smink W, Pellikaan WF, van der Kolk LJ, van der Hoek KW. Methane production as a result from rumen fermentation in cattle calculated by using the IPCC-GPG Tier 2 method. Feed Innovation Services Report FS 0412 E, Utrecht, The Netherlands: National Institute for Public Health and the Environment. 2004.

30. Castelán-Ortega OA. Modeling methane emissions and methane inventories for cattle production systems in Mexico. Atmósfera 2014;27(2):185-191.

31. Morant SV, Gnanasakthy A. A new approach to the mathematical formulation of lactation curves. Anim Prod 1989;49(2):151-162.

32. Ducker MJ, Haggett RA, Fisher WJ, Morant SV, Bloomeld GA. Nutrition and reproductive performance of dairy cattle 1. The effect of level of feeding in late pregnancy and around the time of insemination on the reproductive performance of first lactation dairy heifers. Anim Prod 1985;41(1):1-12.

33. Muylaert de Araujo MS, Pires de Campos C, Pinguelli LR. GHG historical contribution by sectors, sustainable development and equity. Ren Sust Energy Rev 2007; 11(5):988-997. 